\title{
Penggunaan Air Kelapa Muda Sebagai Zat Pengatur Tumbuh Terhadap Daya Kecambah, Vigoritas, Berat Kering Biji Tanaman Kelor (Moringa oleifera)
}

\author{
Dodi Devitriano*, Hutwan Syarifuddin \\ Prodi Peternakan, Fakultas Peternakan, Universitas Jambi \\ *Correspondence email: devitriano65@gmail.com
}

\begin{abstract}
Abstrak. Cara yang lebih umum dilakukan untuk penanaman tanaman kelor adalah menggunakan biji, karena tanaman ini banyak menghasilkan biji. Namun biji yang dihasilkan mempunyai kulit biji yang cukup keras sehingga kondisi tersebut dapat mempengaruhi bahkan menggagalkan terjadinya perkecambahan, vigoritas dan pertumbuhan tanaman tersebut. Penelitian ini bertujuan untuk mengetahui dosis yang tepat dari air kelapa muda untuk digunakan dalam penumbuhan biji tanaman kelor, sehingga nantinya menjadi rekomendasi bagi petani dalam pengembangan tanaman kelor. Penelitian ini dilakukan dengan metode skala rumah kaca dan laboratorium dengan media yang telah disiapkan untuk perkecambahan. Selanjutnya dilakukan pengamatan perkecambahan selama dua minggu untuk mendapat data sesuai dengan parameter yang diamati yang meliputi daya kecambah, vigoritas dan berat kering tanaman kelor. Hasil analisis ragam menunjukkan bahwa perlakuan konsentrasi air kelapa muda berpengaruh tidak nyata $(\mathrm{P}>0,05)$ terhadap daya kecambah, vigoritas dan berat kering tanaman kelor. Begitu pula interaksi antara lama perendaman dan kosentrasi air kelapa muda tidak berpengaruh nyata $(\mathrm{P}>0,05)$ terhadap peubah yang diamati. Keadaan ini dikarenakan tidak semua biji kelor mengalami proses imbibisi secara baik sebingga mempengaruhi peubah yang diamati.
\end{abstract}

Kata kunci: Air Kelapa Muda, Biji Tanaman Kelor

Abstract. The more common methode for planting moringa plant is using seed, because this plant produces a lot of seeds. However, the resulting seeds have a hard enaugh seed coat so that. These conditions can affect and even thwart germination, vigor and growth of the plant. This Study aims to determine the proper dosage of young coconut water to be used in growing moringa seeds, so that later it become a recommendation for formers in the development of moringa plants. This research was conducted using a green house and laboratory scale method with the media that had been prepared for germination obsevations were carried out for two weeks to obtain data according to the observed parameters which included capacity, Vigority and dryweight of moringa plants. The result of the analysis of variety showed that the concentration of young coconut water had no significant effect $(P>0.05)$ on the germination, vigor and dryweight of moringa plants. Likewise, the interaction between immersion time and coconut water concentration had no significant effect $(P>0.05)$ on the observed variables. This situation is due to the fact that not all moringa seeds undergo the imbibition process properly so that they effect the observed variables.

Keywords: Young Coconut Water, Moringa Plant Seeds.

\section{PENDAHULUAN}

Pemenuhan kebutuhan hidup pokok dan berproduksi pada ternak ruminansia, maka hijauan pakan ternak harus tersedia oleh karena itu perlu diperhatikan dari segi kualitas, kuantitas dan kontunyunitas. Sumber hijauan pakan umumnya dapat diperoleh dari jenis rumput - rumputan maupun jenis leguminosa. Dari beberapa jenis leguminosa yang ada tanaman kelor (Moringa oleifera) dapat digunakan sebagai makanan ternak

Tanaman kelor merupakan tanaman tropis yang mudah tumbuh hingga mencapai ketinggian 11 meter dan kebanyakan tumbuh di dataran rendah hingga dataran tinggi sampai ketinggian $700 \mathrm{~m}$ di atas permukaan laut serta termasuk tanaman yang tahan terhadap kekeringan dengan toleransi kekeringan sampai 6 bulan (Mendieta-Araica et al., 2013). Tanaman kelor (Moringa oleifera) merupakan tanaman yang berpotensi sebagai hijauan pakan ternak, yang dapat dijadikan sebagai pakan hijauan tambahan atau campuran pada pakan hijauan yang berkualitas rendah serta sebagai sumber mineral. Melo et al (2013) menyatakan tanaman kelor mengandung 91,19\% bahan kering, 21,54\% protein kasar, $11,20 \%$ lemak kasar, $11,55 \%$ serat kasar, 45,17\% BETN, 11,30\% NDF, 6,86\% ADF dan 10,54\% abu kasar. Tanaman ini juga memiliki banyak manfaat mulai dari daun, buah, biji, bunga, kulit, batang, hingga akar (Fahey, 2005).

Pananaman tanaman kelor dapat dilakukan secara generative yaitu menanam dengan biji, tetapi penanaman dengan biji kelemahannya adalah adanya kulit biji yang keras dan tebal yang dapat berpengaruh masuknya air dan oksigen sehingga dapat menggangu perkecambahan, rendahnya vigoritas dan lambatnya pertumbuhan tanaman. Usaha yang dapat dilakukan untuk melunakkan kulit biji sekaligus mempercepat perkecambahan yaitu dengan cara merendam biji kelor tersebut ke dalam air atau larutan perangsang tumbuh baik yang alami maupun sintetis. Mengingat harga perangsang tumbuh sintesis yang relative cukup mahal maka dicari alterlatif lain yaitu menggunakan zat perangsang tumbuh alami yang relative murah dan mudah didapat. 
Air kelapa muda merupakan cairan yang terdapat dalam buah kelapa dan belum dimanfaatkan secara optimal, biasanya hanya dibuang kemudian diambil daging kelapanya saja. Dalam air kelapa muda terdapat zat pengatur tumbuh seperti giberelin, sitokinin dan auksin (Savitri, 2005). Selain itu juga terkandung senyawa organik seperti zeatin glukosida, sukrosa, fruktosa, protein, karbohidrat, mineral, vitamin, lemak, Ca dan P (Yong et al., 2009). Kandungan ini semua dapat mempengaruhi perkecambahan biji tanaman kelor sehingga nantinya hasil dari perkecambahan ini dapat dijadikan benih atau bahan tanam yang baik

Benih yang berkualitas secara fisiologis dapat terlihat dari daya kecambah,vigoritas dan berat kering tanaman. Daya kecambah merupakan uji kemampuan benih yang dapat tumbuh secara normal namun pengujian secara vigoritas untuk memperoleh kemampuan benih tumbuh normal pada lingkungan yang sub optimal perlu dilakukan juga. Sedangkan berat kering tanaman dapat menjadi tolak ukur pertumbuhan tanaman yang tercermin dari pertambahan jumlah jaringan tanaman pada akar ,batang dan daun.

Berdasarkan pertimbangan diatas maka dilakukan penelitian penggunaan air kelapa muda sebagai zat pengatur tumbuh terhadap daya kecambah, vigoritas, berat kering biji tanaman kelor (Moringa oleifera) sehingga nantinya mendapatkan data hasil penelitian yang lebih lengkap.

\section{Urgensi Penelitian}

Pengembangan tanaman ini sangat penting dilakukan mengingat potensinya cukup yang besar untuk pakan ternak. Pengembangan tanaman kelor dapat dilakukan dengan cara generatif yaitu dengan menggunakan biji, cara ini memberikan banyak keuntungan diantarannya pada produksi biomassa mendapatkan bibit tanaman dalam jumlah besar serta memiliki perakaran yang kuat, sehingga dapat mengembangan tanaman kelor secara banyak dan luas.

Karena biji kelor memiliki kulit yang cukup keras sehingga dapat menghambat masuknya air dan oksigen ke dalam benih akibatnya masa dormansi benih berlangsung lebih lama. Dormansi benih yang lebih lama dapat menurunkan daya kecambah benih dan waktu perkecambahan oleh sebab itu perlu dilakukan suatu perlakuan untuk memecahkan dormansi benih dan mempercepat proses perkecambahan diantaranya dengan merendam biji kelor dalam air kelapa muda

\section{METODE}

\section{Tempat dan Waktu Penelitian}

Penelitian telah dilaksanakan di Laboratorium Hijauan Makanan Ternak dan Rumah Kaca Farm dan Unit Bisnis (FUB) Fakultas Peternakan Universitas Jambi selama 60 hari.

\section{Materi Penelitian}

Bahan yang digunakan dalam penelitian ini adalah benih kelor, ekstrak, air kelapa muda, kapas, aquades. dan tanah PMK ( podzolik Merah Kuning). Sedangkan peralatan yang digunakan yaitu kain kasa , cawan perendaman, ember, cawan petridish, mistar pengukur, cangkul, timbanagn oertling, polibag ukuran $2 \mathrm{~kg}$, dan gelas ukur.

\section{Prosedur Pelaksanaan \\ Persiapan Penelitian}

Persiapan benih mulai dari pemanenan benih $M$. oleifera yang diperoleh dari tanaman kelor di kebun milik salah satu warga yang terletak di Desa Mekar Sari, Muaro Jambi. Jambi. Pengambilan dilakukan dengan cara mengambil benih yang sudah masak fisiologis dengan ciri-ciri polong berwarna coklat, benih kelor yang telah masak fisiologis memiliki kadar air 7-8\% (Paramita et al., 2018). Setelah itu, benih dibersihkan dari kotoran baik berupa pasir maupun kulit polong hingga diperoleh benih yang bersih dan dilakukan seleksi benih berdasarkan berat benih.

\section{Pelaksanaan Penelitian}

Benih kelor yang dipilih seragam dengan prosedur Uji kemurnian benih, yaitu dengan mengambil benih sebanyak 50 gram sebagai sampel. Pengambilan benih dilakukan sebanyak 3 kali, kemudian diletakkan diatas kertas dan dilakukan pemilihan yang meliputi benih murni, benih yang tidak m4urni dan benda-benda lainnya ( ranting, daun, pasir dan kotoran). Selanjutnya dilakukan penimbangan benih bagian-bagian yang sudah dipilih tersebut seterusnya dihitung presentase kemurnian benih.

\section{Penyiapan Air Kelapa Muda}

Buah kelapa yang masih segar dikupas kemudian diambil airnya. Selanjutnya disaring dengan kain kasa sehingga didapatkan air kelapa yang bersih untuk digunakan merendam biji kelor sesuai perlakuan.

Pembuatan Larutan air kelapa dengan cara pengenceran yaitu diencerkan dengan aquades sesuai dengan konsentrasi, dengan mengasumsikan bahwa air kelapa mempunyai konsentrasi $100 \%$. Maka untuk mendapat konsentrasi air kelapa sesuai perlakuan dapat dilakukan pengenceran sebagai berikut:

1. Konsentrasi Air Kelapa Muda 0,0\%

( $0 \mathrm{ml}$ air kelapa muda $+100 \mathrm{ml}$ aquades $)$

2. Konsentrasi Air Kelapa Muda $5 \%$ ( $5 \mathrm{ml}$ air kelapa muda $+95 \mathrm{ml}$ aquades)

3. Konsentrasi Air Kelapa Muda $10 \%$ (10 ml air kelapa muda $+90 \mathrm{ml}$ aquades)

4. Konsentrasi Air Kelapa Muda $15 \%$ (15 $\mathrm{ml}$ air kelapa muda $+85,0 \mathrm{ml}$ aquades) 
Dodi Devitriano dan Hutwan Syarifuddin, Penggunaan Air Kelapa Muda Sebagai Zat Pengatur Tumbuh Terhadap Daya Kecambah, Vigoritas, Berat Kering Biji Tanaman Kelor (Moringa oleifera)

\section{Perendaman Benih}

Tahap ini adalah menyiapkan biji kelor sebanyak 50 butir dimasukkan kedalam tiap-tiap cawan perendaman lamanya perendaman disesuaikan dengan waktu yang telah ditentukan. Waktu perendaman benih diataur agar pengangkatan benih yang telah terendam dapat dilakukan seara serentak untuk semua perlakuan .

Uji daya kecambah dilakukan dengan mengambil 25 butir dari setiap unit perobaan dan dikecambahkan dalam cawan petridish. Media yang digunakan adalah kapas $3 \mathrm{~cm}$ dibasahi sampai air tidak basah lagi.

\section{Rancangan Penelitian}

Rancangan yang digunakan dalam penelitian ini adalah pola factorial dalam rancangan acak lengkap (RAL) dengan 2 faktor perlakuan yaitu:

Faktor pertama tingkat konsentrasi larutan air kelapa muda terdiri dari:

1. Konsentrasi air kelapa muda $0,0 \%(\mathrm{~K} 0)$

2. Konsentrasi air kelapa muda $5,0 \%$ ( K1)

3. Konsentrasi air kelapa muda $10,0 \%$ ( K2)

4. Konsentrasi air kelapa muda 15,0\% (K3)

Faktor kedua adalah lama perendaman benih terdiri dari:

1. Lama perendaman selama 12 jam (P1)

2. Lama perendaman selama 16 Jam (P2)

3. Lama perendaman selama $20 \mathrm{Jam}(\mathrm{P} 3)$

4. Lama perendaman selama 24 Jam (P4)

Dengan demikian terdapat 16 kombinasi perlakuan dengan 3 kali ulangan sehingga jumlah keseluruhan unit penelitian adalah 48 unit percobaan. Untuk menentukan letak unit penelitian dilakukan secara acak.

Untuk mengetahui pengaruh perlakuan terhadap peubah yang diamati dilakukan analisis ragam. Apabila dalam analisis ragam terdapat pengaruh yang nyata dari perlakuan maka dilanjutkan dengan uji lanjut berganda Duncan( Steel dan Torie).

\section{Peubah yang Diamati}

Peubah yang diamati yaitu daya kecambah, vigoritas dan bobot kering tanaman.

\section{Uji Daya Kecambah}

Uji daya kecambah dilakukan dengan mengambil 25 butir dari setiap unit perobaan dan dikecambahkan dalam cawan petridish. Media yang digunakan adalah kapas dengan ketebalan $3 \mathrm{~cm}$ dibasahi sampai air tidak basah lagi.

Selama pengujian diusahakan kapas sebagai media tanamnya dalam keadaan lembab dengan cara meneteskan air. Kemudian dilakukan perhitungan jumlah kecambah yang normal pada hari ke -14 .
Daya Kecambah $=\frac{\text { Jumlah Berkecambah Normal }}{\text { Jumlah benih yang dikecambahkan }} \times 100 \%$

\section{Uji Vigoritas}

Pengujian vigoritas dilakukan dirumah kaca Farm dan Unit Bisnis (FUB) Fakultas Peternakan Universitas Jambi. Pengujian vigoritas dibutuhkan benih kelor sebanyak 25 butir untuk setiap perlakuan. Uji ini dilakukan dengan menanam benih didalam polibag yang telah terisi tanah. Sebelum penanaman, tanah dibasahi dahulu , selanjutnya benih ditanam pasda kedalaman 0,5 $\mathrm{cm}$. Selama pengujian benih sebagai media tanamnya diusakan dalam keadaaan lembab melalui penyiraman setiaphari. Seterusnya dihitung jumlah tanaman yang tumbuh pada hari ke 30 .

$$
\text { Vigoritas }=\frac{\text { Jumlah benih yang tumbuh }}{\text { Total benih yang ditanam }} \times 100 \%
$$

\section{Berat Kering Tanaman}

Setelah dilakukan uji vigoritas dilanjutkan pengukuran berat kering tanaman dengan ara mengambil semua tanaman yang tumbuh pada setiap unit percobaan dan timbang berat segarnya, kemudian dibiarkan kering udara selama 3 hari. Selanjutnys untuk menentukan presentase bahan kering, maka sampel ditimbang kemudian di keringkan dioven selama beberapa jam pada suhu $60{ }^{\circ} \mathrm{C}$, lalu sampel tersebut ditimbang sampai beratnya konstan( berat kering oven). Selanjutnya dihitung presentase bahan kering disetiap unit percobaan. Kemudian ditentukan berat kering tanaman dengan presentase bahan kering dari setiap unit perlakuan.

Bahan Kering $=$ Berat segar $\mathrm{x} \%$ bahan kering.

\section{Analisis Data}

Data yang diperoleh dianalisis menggunakan analisis ragam (ANOVA). Apabila terdapat perbedaan diantara perlakuan maka dilanjutkan dengan uji jarak berganda Duncan (Steel dan Torrie, 1993).

\section{HASIL DAN PEMBAHASAN \\ Daya Kecambah}

Daya kecambah merupakan indikator yang menunjukkan pertumbuhan dan perkembangan dari bagian - bagian penting dari embrio suatu benih untuk menghasilkan tanaman dalam kondisi optimum (Sutopo, 2003).

Hasil rataan daya kecambah benih kelor yang mendapat perlakuan berupa perendaman benih dalam berbagai konsentrasi air kelapa muda dan lama perendaman dapat dilihat pada tabel 1. 
Dodi Devitriano dan Hutwan Syarifuddin, Penggunaan Air Kelapa Muda Sebagai Zat Pengatur Tumbuh Terhadap Daya Kecambah, Vigoritas, Berat Kering Biji Tanaman Kelor (Moringa oleifera)

Tabel 1. Rataan Daya Kecambah Biji Kelor (\%) Pada Berbagai Konsentrasi Air Kelapa Muda dan Lama Perendaman.

\begin{tabular}{cccccc}
\hline Konsentrasi & \multicolumn{5}{c}{ Lama Perendaman (Jam) } \\
\cline { 2 - 5 }$(\%)$ & 12 & 16 & 20 & 24 & \\
\hline 0 & 41,333 & 42,667 & 44,000 & 46,667 & 43,666 \\
5 & 44,000 & 44,000 & 46,667 & 47,667 & 45,583 \\
10 & 46,667 & 48,000 & 48,000 & 49,333 & 48,000 \\
15 & 49,333 & 48,000 & 50,666 & 52,000 & 49,999 \\
Rataan & 45,333 & 45,667 & 47,333 & 48,916 & \\
\hline
\end{tabular}

Tabel 1 terlihat bahwa daya kecambah tertinggi diperoleh pada perlakuan konsentrasi air kelapa muda $15 \%$ dan lama peredaman selama 24 jam. Namun analisis ragam menunjukkan bahwa perlakuan tingkat konsentrasi dan lama perendaman tidak memberikan pengaruh nyata $(\mathrm{P}>0,05)$ terhadap daya kecambah.

Penyebab tidak berpengaruhnya perlakuan terhadap daya kecambah, disebabkan tidak semua benih mengalami terjadinya proses imbibisi ketika biji direndam didalam air kelapa muda. Tidak terjadinya proses imbibisi pada sebagian benih disebabkan oleh kandungan zat asam yang tedapat dalam air kelapa muda tersebut belum mampu melunakkan kulit biji kelor yang cukup keras dan tebal. Fessenden dan Fessenden (2006) mengatakan asam-asam yang terdapat didalam air kelapa muda seperti asam sitrat dan malat tergolong asam lemah. Gardner et al (2009) mengatakan bahwa kulit benih leguminosa pohon mempunyai lapisan shelenoid dan malpighi yang kompak dan padat sehingga bersifat kedap air serta adanya senyawa fenolik yang bersifat menahan air.

Dugaan lain yang menyebabkan perlakuan tidak berpengaruh nyata terhadap daya kecambah, diduga geberelin dan sitokinin yang terdapat didalam air kelapa muda hingga konsentrasi $15 \%$ belum dapat merangsang pertumbuhan sel sehingga tidak semua benih mampu menghasilkan kecambah yang normal, Krisnadi (2015) bahwa geberelin dan sitokinin dapat mempertinggi aktifitas pembelahan sel tanaman.

\section{Vigoritas}

Vigoritas merupakan indikasi viabilitas benih yang menggambarkan benih dapat tumbuh dengan baik dilapangan dengan kondisi lingkungan yang sub optimum (Sadjad, 2013). Hasil rataan vigoritas biji kelor yang direndam dalam larutan air kelapa muda pada berbagai konsentrasi dan lama perendaman terlihat pada tabel 2.

Tabel 2. Rataan Vigoritas Biji Kelor (\%) Pada Berbagai Konsentrasi Air Kelapa Muda dan Lama Perendaman.

\begin{tabular}{cccccc}
\hline Konsentrasi & \multicolumn{5}{c}{ Lama Perendaman (Jam) } \\
\cline { 2 - 5 }$(\%)$ & 12 & 16 & 20 & 24 & \\
\hline 0 & 44,000 & 45,333 & 46,667 & 48,000 & 46,000 \\
5 & 48,000 & 48,000 & 49,333 & 49,333 & 48,666 \\
10 & 49,333 & 49,333 & 50,667 & 52,000 & 50,333 \\
15 & 52,000 & 52,000 & 53,333 & 53,333 & 52,666 \\
Rataan & 48,333 & 48,666 & 50,000 & 50,666 & \\
\hline
\end{tabular}

Hasil analisis ragam menunjukkan bahwa perlakuan tingkat konsentrasi air kelapa muda dari lama perendaman benih serta interaksi keduanya tidak berpengaruh nyata $(\mathrm{P}>0,05)$ terhadap vigoritas .

Tidak terdapatnya pengaruh perlakuan terhadap vigoritas, dikarenakan sejak awal sudah tidak terjadinya proses imbibisi untuk semua benih ketika dilakukan perendaman didalam larutan air kelapa muda. Bila proses imbibisi tidak berlangsung dengan baik menyebabkan enzim tidak dapat berfungsi untuk mencerna zat-zat makanan yang tersedia didalam benih dan akan disalurkan ketitik tumbuh untuk dimanfaatkan pada proses pertumbuhan. Menurut Kamil (2009) bahwa enzim yang terdapat didalam benih berfungsi untuk merombak pati dan hemisellulosa menjadi gula, lemak menjadi gliserol dan asam lemah serta protein dan asam lemah menjadi asam amino.

Walaupun interaksi konsentrasi air kelapa muda dan lama perendaman tidak berpengaruh nyata terhadap vigoritas benih, akan tetapi nilai rataan vigoritas cenderung meningkat, apabila semakin tinggi tingkat konsentrasi air kelapa muda dan lama perendaman benih. Hal ini terlihat pada tabel 2 bahwa vigoritas tertinggi didapatkan pada perakuan pada tingkat konsentrsai air $15 \%$ dan lama perendaman 24 jam.

\section{Berat Kering Tanaman Kelor}

Berat kering tanaman mencerminkan kandungan bahan kering dalam jaringan tubuh tanaman dan juga mencerminkan besarnya produksi yang dihasilkan (Kamil, 2009). Data rataan berat kering tanaman kelor pada berbagai konsentrasi dan lama perendaman dapat dilihat pada tabel 3 .

Tabel 3. Rataan Berat Kering Tanaman Kelor (gr/polybag) Pada Berbagai Konsentrasi Air Kelapa Muda dan Lama Perendaman

\begin{tabular}{cccccc}
\hline \multirow{2}{*}{$\begin{array}{c}\text { Konsentrasi } \\
(\%)\end{array}$} & \multicolumn{4}{c}{ Lama Perendaman (Jam) } & \multirow{2}{*}{ Rataan } \\
\cline { 2 - 5 } & 12 & 16 & 20 & 24 & \\
\hline 0 & 0,213 & 0,220 & 0,220 & 0,227 & 0,220 \\
5 & 0,227 & 0,227 & 0,233 & 0,240 & 0,232 \\
10 & 0,233 & 0,240 & 0,247 & 0,247 & 0,242 \\
15 & 0,247 & 0,253 & 0,253 & 0,260 & 0,253 \\
Rataan & 0,230 & 0,235 & 0,238 & 0,243 & \\
\hline
\end{tabular}

Hasil analisis ragam menunjukkan bahwa perlakuan tingkat konsentrasi air kelapa muda dan lama perendaman biji kelor serta interaksi keduanya tidak berpengaruh nyata $(\mathrm{P}>0,05)$ terhadap berat kering tanaman.

Dugaan yang menyebabkan tidak berpengaruh nyata perlakuan terhadap berat kering tanaman adalah berkaitan dengan daya kecambah dan vigoritas yang juga tidak dipengaruhi oleh perlakuan. Kondisi tersebut tentu mempengaruhi pertumbuhan bahan kering tanaman. Suseno (2015), kemunduran benih diartikan sebagai rendahnya viabilitas yang mengakibatkan menurunnya vigoritas, jeleknya pertumbuhan dan produksi. 
Dugaan yang lain menyebabkan tidak berbeda nyatanya berat kering tanaman antar perlakuan adalah kondisi media tumbuh tanaman yang hanya terdiri dari tanah dan air, tanpa pemberian pupuk selama 30 hari penanaman. Sehingga mempengaruhi hasil fotosintesis tanaman yang digunakan untuk pertumbuhan yang tercermin dari pertambahan ukuran dan berat kering tanaman. Gardner (2009) menyatakan bahwa pertumbuhan tanaman ditunjukkan oleh pertambahan, ukuran dan berat kering menandakan tanaman mengalami pertumbuhan selanjutnya. Setyati (2003) menambahkan bahwa pertumbuhan tanaman ditunjukkan oleh pertambahan, ukuran dan berat kering suatu organisme tercermin dari bertambahnya protoplasma yang terjadi karena ukuran sel maupun jumlahnya bertambah.

\section{SIMPULAN}

Berdasarkan analisis statistik dan pembahasan dapat ditarik kesimpulan bahwa perendaman biji kelor dalam air kelapa muda memperlihatkan nilai rataan yang cenderung meningkat hingga konsentrasi $15 \%$ dan lama perendaman 24 jam. Namun demikian dari analisis statistik belum memberikan pengaruh nyata terhadap daya kecambah vigoritas dan berat kering tanaman kelor.

\section{Saran}

Perlu dilakukan penelitian lebih lanjut dengan tingkat konsentrasi yang lebih tinggi dan waktu perendaman yang lebih lama, sehinga dapat meningkatkan secara nyata terhadap daya kecambah Vigoritas dan berat kering tanaman kelor

\section{DAFTAR PUSTAKA}

Fahey, J.W. 2005. Moringa oleifera A review of the medical evidence for its nutritional therapeutic and prophylactic properties. Trees Life Journal. $1: 157-164$.

Fessenden, RJ dan J. S. Fessenden. 2006. Kimina Organih. Edisi kelima.terjemahan Hadayana Alosius Pudjaatmaka. Penerbit Erlangga

Gardner, F.P, R.B. Pearce dan R.L. Mitchell (2009). Fisiologi Tanaman Budidaya. Terjemehan Herawati Susilo . Universitas Indonesia Press Jakarta.

Kamil, 2009. Teknologi Benih Departemen Agronomi Fakultas Pertanian Universitas Andalas, Padang.

Krisnadi, AD. 2015. Kelor Super Nutrisi. Morindo. Blora. Jawa Tengah.

Melo, V., N. Vargas, T. Quirino, and C.M.C. Calvo. 2013. Moringa oleifera Lamk An underutilized tree with macronutrients for human health. Emirates Journal of Food and Agriculture. 25:785-789.

Mendieta-Araica, B., E. Spörndly, N. Reyes-Sánchez, F. Salmerón-Miranda, and M. Halling. 2013.
Biomass production and chemical composition of Moringa oleifera under different planting densities and levels of nitrogen fertilization. Agroforestry System 87:81-92.

Paramita, K.E., T.K. Suharsi, dan M. Surahman. 2018. Optimasi pengujian daya berkecambah dan faktor yang mempengaruhi viabilitas dan vigor benih kelor (Moringa oleifera Lam.) dalam penyimpanan. Buletin Agrohortikultura 6:221230.

Sadjad, S (2013). Beberapa Parameter Baru untuk Vigor Benih Jagung, Simposium I Peranan Hasil Penelitian dari palawija dalam pembangunan Pertanian.

Savitri SVH. 2005. Induksi Akar Stek Batang Sambung Nyawa (Gynura drocumbens (Lour) Merr.) Menggunakan Air Kelapa. Skripsi. Fakultas Matematika dan Ilmu Pengetahuan Alam. Institut Pertanian Bogor. Bogor

Setyati, H.S. 2003. Pengantar Agronomi, PT. Gramedia Jakarta.

Sutopo, L. 1985. Teknologi Benih. Cv. Rajawali. Jakarta Tefa, A. 2017. Uji viabilitas dan vigor benih padi (Oryza sativa) selama penyimpanan pada tingkat kadar air yang berbeda. Jurnal Pertanian Konservasi Lahan Kering 2:48-50.

Suseno, H. 2015. Dasar - dasar Teknologi benih capeta selecta, Departemen Agronomi IPB, Bogor.

Steel, R.G.D., Torry, J.H., 1993. Prinsip dan Prosedur Statistika. PT. Gramedia Utama. Jakarta.

Yong, J.W.H., Ge, L., Ng, Y.F. and Tan, S. 2009. The Chemical Composition and Biological Properties of Coconut (Cocos nucifera L.) Water. Molecules. 14, 5144-5164. 